\title{
Student Perceptions of the Impact of Bursaries and Institutional Aid on their Higher Education Choices and the Implications for the National Scholarship Programme in England
}

\section{Claire Callender* and David Wilkinson**}

\author{
*Birkbeck and Institute of Education, University of London, 26 Russell Square, London, \\ WC1B 5DQ \\ email: c.callender@bbk.ac.uk
}

**National Institute for Economic and Social Research

2 Dean Trench Street, Smith Square London, SW1P 3HE

Email: D.Wilkinson@niesr.ac.uk

\begin{abstract}
Variable tuition fees and bursaries, funded by higher education institutions, were introduced in England to promote student choice and provider competition, while bursaries would off-set higher fees and safeguard access. Both have been central to government reforms of student funding since 2004. This article assesses student perceptions of the impact of bursaries on their higher education decisions and choices, and considers the implications for the 2012/13 National Scholarship Programme. It concludes that most students do not think their choices are affected by bursaries although those who: are cost-conscious; expect to receive higher bursaries, especially of $£ 1,000$ or more; and attend Russell Group universities are more likely to think bursaries are influential and important. The reconfiguration of institutional aid from 2012/13 may overcome some perceived barriers to the effectiveness of financial support, but is likely to exacerbate others, and create new impediments and inequalities.
\end{abstract}

\section{Introduction 1}

The expansion and growing importance of higher education (HE) in England since the 1980s have prompted numerous reforms aimed at reshaping and restructuring student finance, reflecting the changing ideological, economic, and social functions of HE. The student funding reforms introduced in England by the 2004 Higher Education Act, especially the launch of financial assistance in the form of bursaries funded by higher education institutions (HEIs), the focus of this paper, were particularly significant. Bursaries alongside higher, variable tuition fees were to embody the Labour government's quest for an HE quasi-market. Together they would establish price differentials among universities to promote provider competition and student choice, while bursaries also would help off-set tuition fee increases

\footnotetext{
${ }^{1}$ We are very grateful to the anonymous reviewers for their very helpful and constructive comments.
} 
to safeguard HE access by lowering the cost of HE participation. Both policy tools lie at the heart of the Westminster Coalition's 2012/13 HE funding reforms and their goal of completing Labour's marketisation agenda. The Coalition increased undergraduate tuition fees threefold and boosted the role of institutional aid through the National Scholarship Programme (NSP) which they co-fund. In 2010/11 universities and colleges spent $£ 378.1$ million on bursaries and scholarships for low-income students (OFFA, 2012a) and plan to spend $£ 443.9$ million on financial support in 2013/14 while the government will be investing $£ 150$ million in NSP (OFFA, 2012b). Significantly, too, bursaries reflect the ongoing trend in welfare provision towards discretionary benefits and decentralised or 'localised' decisionmaking (Hills and Richards, 2012) as each university designs its own system of support with widely varying eligibility criteria.

Despite considerable investment in bursaries in England, little is known about student perceptions of their effectiveness in promoting HE access and choice because until now they have not been examined systematically in England. This article presents such an analysis and considers the implications for the NSP, drawing on the findings of the first major national study of bursaries which included a survey of 4,848 full-time undergraduates entering HE for the first time in 2008/09. The article concludes that most students do not believe their choices are affected by bursaries. This is partly because of a lack of bursary information and poor marketing, and partly because bursaries are poorly designed, undermining their effectiveness. The reconfiguration of institutional aid from 2012/13 under the NSP may overcome some of the perceived barriers to the effectiveness of institutional aid, but also is likely to exacerbate others and create new impediments and inequalities.

The article focuses exclusively on student financial support in England for full-time undergraduates, ${ }^{2}$ although the lessons learnt are more far-reaching, especially for countries like the US where institutional aid is central and growing in importance. In 2008-09, US institutions provided about $\$ 24$ billion in grants to undergraduate students. Institutional grants increased from 34 per cent of total undergraduate grant aid in 1990-91 to 40 per cent in 200001, and were 39 per cent of the total in 2008-09 (Baum et al., 2010). Consequently, only about one-third of full-time US students now pay the full published tuition fee and other fees (College Board, 2011).

For context, the article starts by discussing the Labour government's 2004 HE student funding reforms and the Coalition's 2012/13 reforms, highlighting the policy continuities between them. Next, the article examines the research context looking at evidence on the impact of financial aid on HE participation. Then we turn to the study's findings about student perceptions of their awareness, knowledge and understanding of bursaries and their assessment of bursaries' impact on their choice of HEI. The article concludes by discussing some of the implications of the findings for the new form of institutional aid under the NSP.

\footnotetext{
2 HE policy within the UK is devolved. The reforms discussed relate only to English domiciled students studying in England but do have implications for other UK and EU students.
} 


\section{The policy context}

The growing importance of, and demand for, HE; the increasing costs of HE driven by its expansion and rising per-student costs, including student financial support; the inadequacy, to date, of cost-side solutions to solve these problems; and constraints on public expenditure have put considerable pressure on the ability and willingness of governments, both in England and abroad, to meet these costs. The challenge for the Coalition, as it was for the previous Labour administration, is to provide a viable student finance system and, in line with their wider HE policy objectives, to create a system of financial support which also encourages access, enhances student choice, and increases competition among HE providers to establish a more diverse, efficient HE sector.

The policy response in England (and elsewhere) has been to reduce HE public expenditure and shift costs from government and taxpayers towards students and/or their parents. Underpinning this 'cost-sharing' agenda (Johnstone and Marcucci, 2010) are the private returns to $\mathrm{HE}$, and gradual transformations in beliefs about $\mathrm{HE}$, its role in society, who benefits, and so who should pay. All major HE student funding reforms in Britain since 1990 have sought to restructure this balance of private and public contributions.

A second driver of student funding reform, also ideological, is the quest to create a HE quasimarket. User choice and provider competition were central to Labour's modernisation agenda and their public services reforms, including HE, placed the consumer centre-stage (Vindler and Clarke, 2005; Clarke et al., 2007). These policy technologies (Ball, 2008) steered Labour's HE policies, were crucial to their 2004 Higher Education Act, and are central to the Coalition's reforms.

The Labour government's 2004 Higher Education Act, which came into force in 2006, launched variable tuition fees for full-time undergraduate courses capped by government at $£ 3,000{ }^{3}$ All full-time students were eligible for income-contingent student loans to cover all their tuition fees, and loans for maintenance that pre-date the 2004 Act. The loans were repaid on graduation when earning above $£ 15,000$ per annum, and attracted a zero real interest rate. Simultaneously, a package of financial support was introduced for low-income students because of concerns about the impact of increased fees on participation. This included the re-introduction of government-funded means-tested maintenance grants, and the establishment of cash bursaries funded by universities. Consequently, low-income students qualified for grants, loans, and bursaries towards their living costs while their more affluent peers were eligible just for loans.

Bursaries were seen by government as a policy device for: overcoming the financial barriers to HE participation, including minimising the impact of higher tuition fees; reducing student debt and promoting student choice; and safeguarding access (Callender, 2010). Two types of bursaries were introduced in 2006. First, mandatory bursaries, worth $£ 338$ in 2011/12, and paid only to students in receipt of a full maintenance grant and attending an HEI charging the maximum tuition fees. These criteria and sums were universal and fixed, set centrally by government. Second, non-mandatory discretionary bursaries offered to these and other students, with HEIs determining eligibility and value.

3 The cap was to rise in line with inflation each academic year. 
Both types of bursaries funded by HEIs, mainly from additional tuition fees, were given in cash throughout the duration of a student's course. To facilitate their take-up and administration, the Higher Education Bursary and Scholarship Scheme (HEBSS) was established. HEBSS was run by the Student Loans Company (SLC), a UK public sector organisation which administers government funded student loans and maintenance grants: it automatically assessed students' eligibility for bursaries at their chosen HEI when students applied for other government-funded financial support.

In 2010/11, HEIs spent on average 21.6 per cent of their additional tuition fee income on bursaries. This varied significantly by HEI ranging from 5 to 36 per cent (OFFA, 2012a), and by type of HEI with Post-1992 universities, less research intensive HEIs attracting the most low-income students, devoting the highest share (National Audit Office, 2008). In 2008-09, 79 per cent of HEIs providing mandatory bursaries offered bursaries above the statutory minimum, while 94 per cent provided discretionary bursaries with additional eligibility criteria (OFFA, 2010). Consequently, there were hundreds of different bursaries, with most HEIs having multiple schemes. By 2010/11, the average bursary for the poorest students was $£ 877$, but was three times larger for those attending research-intensive Russell Group universities $(£ 1,576)$ compared with those attending Million+ universities (£584) - made up of post-1992 HEIs (OFFA, 2010). ${ }^{4}$

The 2004 Higher Education Act aimed to promote a more market-orientated system of HE through both variable tuition fees and bursaries. Together they would establish price differentials among HEIs and generate more price competition which would influence student choice. However, by 2010/11, all universities were charging the maximum fees for bachelor's degrees and this became a new flat rate fee. Any competitive advantage of charging lower fees was outweighed by the benefits of higher fee income. In contrast, there was significant variability in bursaries which reduced the net price of courses for students. HEIs were using these bursaries to meet their wide-ranging enrolment goals, as part of their widening participation strategy, and as a competitive recruitment tool to protect their market share (Callender, 2010).

The 2004 reforms ended the principle of universalism: that all students, irrespective of where and what they studied, should be treated the same, pay the same tuition fees, and receive the same types and amount of financial support if they met universal and fixed government-set national eligibility criteria. They also established the idea of institutional aid - whereby HEIs should provide students with financial support but HEIs, not the state, should select the beneficiaries and what they receive. Consequently, for the first time, discretionary rather than universal financial support became widespread, just like in the US (Baum, et al., 2010). The Coalition's reforms, outlined in the 2011 White Paper, Higher Education: Students at the Heart of the System (BIS, 2011), and introduced in 2012/13, aim to make HE financially sustainable, to improve the student experience, and increase social mobility. ${ }^{5}$ They are similarly motivated by a desire to reduce both student support costs and HE public expenditure, in line with their broader strategy to cut the fiscal deficit and stimulate economic

\footnotetext{
${ }^{4}$ For a fuller discussion of the different type of bursaries available and their diverse eligibility criteria see Callender,2010

${ }^{5}$ For a critique of these reforms see Barr (2012) and Callender (2012).
} 
growth in the context of a global recession. Their ideologically-driven vision is of an $\mathrm{HE}$ sector defined by the market which they believe delivers high-quality services efficiently, equitably, and is responsive to consumer choice (BIS, 2011).

The government withdrew universities' teaching grants for most undergraduate courses and HEIs' lost income was replaced through higher tuition fees. The government-set cap on fees rose from a maximum of $£ 3,290$ to $£ 9,000$ for full-time undergraduate courses and to $£ 6,750$ for part-time courses. All students, as before, can repay their fees on graduation through income-contingent loans. ${ }^{6}$ Consequently, there is no, or limited, taxpayer support for teaching with these costs being met by students paying higher fees. Government support for undergraduates, therefore, has shifted from teaching grants to student loans - from a block grant to private contributions from individual students in line with the idea of cost-sharing. Ultimately, these changes valorise the private benefits of $\mathrm{HE}$ at the expense of the public benefits, and do not question the private subsidy of public benefits, positioning $\mathrm{HE}$ as a private investment rather than as a public good (Reay, 2012).

As before, all full-time students qualify for students loans towards their maintenance costs. To reduce government's costs of providing loans for maintenance and tuition and extending them to part-times students, the interest rate was increased and a sliding scale, up to a maximum of inflation plus 3 per cent when graduates' earnings exceed $£ 41,000$ per year, was introduced. Students continue to pay 9 per cent of their income above $£ 21,000$ (up from $£ 15,000)$ until they have repaid all their loans, with any outstanding debt written-off after 30 years, up from 25 .

In 20012/13, full-time students from low-income families still qualify for maintenance grants. Although means-tested mandatory bursaries funded by HEIs were abolished, the more valuable discretionary, non-mandatory bursaries are continuing for low-income and other students. In addition, some students in 2012/13 from households with incomes of $£ 25,000$ or less, attending institutions charging fees above $£ 6,000$, can get financial support under the new co-funded National Scholarship Programme (HEFCE, 2011). HEIs have been allocated by government a fixed number of Scholarships of $£ 3,000$ each, and are required to match fund their allocation at 100 per cent if charging fees above $£ 6,000$. Students' eligibility is determined by these government-set criteria plus additional ones set by individual HEIs, with each student receiving a minimum $£ 3,000$ benefit. The benefit, determined by each HEI, can be cash bursaries (capped at £1,000), fee waivers and/or aid in kind. The NSP aims to complement rather than replace existing bursaries and, as discussed, both attract considerable investment, with HEI's financial support absorbing 18.8 per cent of their tuition fee in 2013/14 (OFFA, 2012a). Consequently, under the new funding regime, bursaries will continue to play a significant role in student funding.

The Coalition, like their predecessors, are using differential tuition fees and institutional aid to increase competition among HE providers and by giving students loans, which in effect, are like an educational voucher that students redeem at the institution of choice. In line with market principles, the bulk of universities' money will follow students' choices while,

\footnotetext{
6 Part-time undergraduate students, for the first time, also qualify for student loans but only for their tuition fees and only if they are studying more than $25 \%$ of a full-time course and do not already hold a level 4 qualification. For a detailed examination of student support for part-time undergraduates see Callender 2013.
} 
theoretically, consumer demand will determine what HEIs offer, students will be better informed through the provision of more information, while HEIs will compete on price to attract students, including discounts through fee waivers, bursaries, and the NSP.

Detailed information on these government-funded student loans and grants is available on university websites or from the government's website gov.uk, which includes what help students can get, how much they will receive, who qualifies, and how to apply. In theory, with the aid of this website's 'student finances calculator' (https://www.gov.uk/studentfinance-calculator), potential HE students can work out their eligibility to government-funded financial support and how much they will receive personally, well in advance of any HE decision-making. In other words, potential students can gain both predictive information on eligibility as well as specific personal information. However, neither this student finance calculator nor this website can provide such details or information for fee waivers, bursaries and the NSP because of their diversity and their varying discretionary eligibility criteria. The website tells would-be students that 'Each university or college has their own rules about bursaries, scholarships and awards' and instructs them to 'Talk to your student support service to find out what's available' (https://www.gov.uk/extra-money-pay-university). In reality, as we will see, most, but not all, students do not receive either predictive or personalised information directly about bursaries until after they had made their HE choices, and sometimes not until they start their course. And as discussed, the information provided on individual university websites often lacks transparency. As will be argued, this represents a problem for the system of bursaries and financial aid as a whole, as well as a problem in disseminating information. But above all, it means that such financial support cannot inform the potential students' decisions about whether to enter higher education, and if so, where to apply. It cannot incentivise participation among students from disadvantaged backgrounds.

\section{The research context}

There is a growing body of research examining the complex interaction of social, economic, and cultural factors and inequalities underpinning students' educational 'choices', including whether to enter HE, their choice of HEI, subject, and qualification ( e.g. Bates et al., 2009; Raey et al., 2005; Burchardt, 2005). Studies here and in the US suggest that financial concerns and material constraints affect student decision-making, especially among lowincome and 'non-traditional' students (e.g. Usher et al., 2010; Long, 2008).

The primary goal of all student financial support policies is to lower the cost of going to university, whether to address social externalities, credit constraints, or information failures. A review of 156 international studies on the impact of tuition fees and student financial support on HE participation (London Economics, 2010) concludes that university tuition fees have a negative impact on participation, and fee increases tend to cause a decline in participation, particularly among students from lower socioeconomic backgrounds, unless accompanied by equivalent increases in student support. Tuition fees and other educationrelated costs also influence students' selection of HEI, their behaviour whilst at university and reduce the probability of completion, especially for students from Black and Minority Ethnic groups and lower socioeconomic backgrounds. The provision of grants and bursaries, and increases in student support levels, do enhance both HE participation and the probability of students completing their studies. A review of US research (Mundel, 2008) confirms the 
effectiveness of grants, bursaries and fee waivers in influencing both participation and university choice, and the greater the aid's value, the greater its potential impact.

When conducting our study, little research in England had investigated students' attitudes towards bursaries or their perceived impact on student decision-making. The 2007/08 Student Income and Expenditure Survey finds a third of full-time undergraduates receive bursaries but did not examine their effects (Johnson et al., 2009). Davies et al.'s (2008) study of final year school pupils concludes most did not seek bursary information nor consider bursaries when choosing their university and course. While this study provides useful insights on prospective HE students, the sample was not representative of that entire population. These gaps in the existing research prompted our study.

Subsequently, Corver (2010) investigated whether differential bursaries have changed 18-19 year olds' HE choices. Using existing administrative data, he concludes that disadvantaged young people have not been influenced by the size of bursary available when making university choices and are not more likely to apply to HEIs offering higher bursaries. Nor has this group become more likely to choose an HEI offering a higher bursary when they are offered a place, and there has been no material increase in the take-up rate by them at HEIs offering higher bursaries.

Corver's conclusions vary somewhat from ours, which can be attributed to important differences in our respective studies. First, our analysis is based on survey data while Corver's relies on administrative data. This allowed us to explore students' awareness, and knowledge of bursaries and attitudes towards them, unlike Corver's modelling. Second, our respective data relate to different time periods. Our study was undertaken when students were starting their HE course, while Corver's focused on when students were applying to HEIs, nearly a year earlier. Consequently, our students had had more time to familiarise themselves with bursaries. Thirdly, our data include undergraduates of all ages, not just 18-19 years. Finally, our study is about students' perceptions, while Corver's charts their actual behaviour. Debates about the relationship between attitudes and behaviour have a long history in social science. Yet, the potentially powerful impact of misplaced perceptions of actuality on behaviour is well established (Kettley et al., 2007).

\section{The study}

The study explored awareness of, and attitudes towards, bursaries in England (Callender, 2009a) and their impact on students from students' owns perspectives (Callender et al., 2009), and that of their parents' (Callender and Hopkin, 2009), HEIs' (Callender, 2009b), and HE advisors' in schools and colleges (Callender, 2009c). The remit of our study, therefore, was much broader than Corver's (2010). Here we focus on findings from our student survey. The survey consisted of a stratified random sample of full-time undergraduates entering HE for the first time in 2008/09; two years after bursaries were first introduced. All students were attending English HEIs charging the maximum tuition fee of $£ 3,145$, and all were in receipt of government-funded maintenance grants because they are the key (but not the sole) beneficiaries of bursaries. The sample was drawn from the Student Loans Company records which is the only centralised sampling source containing data both on students' household income and their contact details. It was structured so that two-thirds were students in receipt of a full grant (i.e. from households with residual incomes $£ 25,000$ or below) and a third were 
in receipt of a partial grant (i.e. from households with residual incomes between $£ 25,001$ and $£ 60,005)$.

The survey was conducted in October 2008 as the students were about to start, or had just started, their HE courses. The data were collected using an online self-completion questionnaire. 5,152 out of 20,000 questionnaires distributed were completed, yielding a 25.76 per cent response rate. 304 respondents were removed from the sample, leaving 4,848 respondents. Demographic data on students collected by the SLC were linked to the responses. Final data were weighted to the national profile of students by gender, whether the student received a tuition fee loan, and the date their student record was created by the SLC (Callender et al., 2009).

\section{The sample}

The majority of the students surveyed fell into the following categories: female (57\%), under the age of $25(87 \%)$, white $(73 \%)$, single (94\%) and childless (92\%) (Table 1). Given the sample design, two-thirds came from families with an annual household residual income of $£ 25,000$ or less and were in receipt of a full state maintenance grant while the third with residual household incomes between $£ 25,000$ and $£ 60,005$ and received a partial grant. Half had parents without a HE qualification. The majority had undertaken their HE entry qualification at a FE College (65\%), were studying at a Post-1992 university (59\%), attended universities that subscribed to the full HEBSS service (78\%), and were not studying a subject deemed by the Higher Education Funding Council (HEFCE) who distributes public money for $\mathrm{HE}$, to be strategically important or vulnerable (SIV), such as science and foreign languages (84\%) (Table 2).

\section{INSERT TABLE 1 and TABLE 2 ABOUT HERE}

\section{Findings}

Awareness of Bursaries

Knowledge of the existence of bursaries is fundamental to their effectiveness for promoting student choice, provider competition, and protecting access. As Dynarski and Scott-Clayton (2006: 320) comment in relation to the US, 'potential college students cannot respond to a price subsidy if they do not know it exists'. A quarter (24\%) of students surveyed had not heard of bursaries, even though all were just about to enter HE, and most were eligible for them, given their household income. Students' awareness of bursaries varied by their background. Multivariate analysis, which controlled for a broad range of socio-economic and institutional characteristics (Table 3), confirmed statistically significant associations between the probability that a student had not heard of bursaries and students' household income, ethnicity, type of institution attended, and the HEBSS status of their HEI. High-income household students, those least likely to qualify for bursaries, are the least aware. Asian and Black students are more likely than White students to consider themselves unaware of bursaries. This matters because Asian and Black respondents come from some of the poorest households, and are more worried about the costs of going to university and about building up debt while at university than any other student group. This suggests that students with financial needs may be putting their HE access at risk. 
Students at Russell Group universities judge themselves more aware than those studying at post-1992 and more-research intensive pre-1992 universities (incorporated before and after 1992), which cannot be explained by variations in the socio-economic composition of these HEIs because this was controlled for in our modelling. It suggests that either Russell Group universities are particularly good at providing potential students with information on bursaries and marketing them; or that students who are more likely to seek information on bursaries are more likely to attend Russell Group HEIs. Further, the type of HEBSS membership is significant. HEIs could subscribe to a full service which notified students and processed bursaries on an HEI's behalf, or a partial service, which only identified an HEI's eligible students. Students attending HEIs subscribing to the full HEBSS service report less bursary awareness than students at HEIs with a partial service, suggesting the former either may be complacent about disseminating bursary information and/or may have a false sense of security about bursary awareness because of their HEBSS membership. In turn, this implies that HEBSS is not doing a particularly good job in terms of notifying students about bursaries.

\section{INSERT TABLE 3 ABOUT HERE}

\section{Students' understanding of bursaries}

Another factor impacting the effectiveness of bursaries is students' knowledge and understanding of bursaries. Students need to know what bursaries are, otherwise they are not useful for choice and competition, or access. We asked all students how well-informed they thought they were about the various sources of student financial support. The vast majority thought they were very or fairly well-informed about loans for tuition fees $(88 \%)$ and maintenance $(82 \%)$, and grants $(80 \%)$ but only 47 per cent thought this about bursaries, mirroring earlier research findings (Davies et al., 2008). This cannot be attributed to the fact that bursaries were new because loans for tuition fees were introduced at the same time, but rather suggests a serious information and marketing or dissemination gap in relation to institutional financial support in contrast to government-funded student financial support.

Furthermore, students who were aware of bursaries were asked if they understand what is meant by a bursary, the vast majority ( $84 \%$ ) believed they did. Our multivariate analysis (Table 4) reveals particularly large correlations between students' perceived understanding of bursaries and information-seeking behaviour. Students claiming they did not seek bursary information are 22 per cent less likely to think they understand what bursaries are than those saying they looked, while students who believe there is not enough bursary information are less likely to grasp what bursaries are than those thinking there is enough. Students' information-seeking behaviour and the amount of information available seems associated with student perceptions of bursary knowledge.

The type of HEI students attend also seems to matter. Again, Russell Group universities stand out. Students at these universities are more likely than those at post-1992 and 1994 universities to comprehend bursaries. Again, Black students are less likely than White students to say they understand what bursaries are. 


\section{INSERT TABLE 4 ABOUT HERE}

When students are informed about the bursaries they will receive

For bursaries to incentivise HE participation and influence students' HE choices, students need to know whether, what, and how much they will receive. This can be difficult to ascertain from university websites (Diamond et al., 2012), students' main source of bursary information, because many discretionary bursaries have complex and opaque eligibility criteria. Specifically, students need this information in time to inform their decisions about whether to enter HE and where to study. US research (Hossler et al., 1998) identifies two stages in students' decision-making that could be affected by financial support. The 'searching' stage, when students search out courses and consider their options, which equates to the period up to students submitting their Universities and Colleges Admissions Service (UCAS) application form detailing the five HEIs they wish to apply to. And the 'choice' stage, once students are offered a university place and choose which offer/s to accept. In fact, students in England, like many of their peers in the US, are not told about their bursary eligibility and its value when offered a university place. They are notified only after they accept a place, when it is too late to inform their entry decision and HEI choice. It was also at this point that survey respondents most frequently looked for bursary information, although 30 per cent report not looking for information at all. And confirmation of bursary receipt may come very late. A third of students surveyed had not yet been told whether or not they would receive a bursary, despite the fact that they were surveyed in October 2008 and had started their HEI course, or were about to. If bursaries are to inform student choice effectively and support access, students need to know about their bursary eligibility and its value much earlier in the application cycle.

So how important do student think bursaries are in their decision-making?

\section{Assessing the perceived impact of bursaries}

We investigate two aspects of students' perceptions of the impact of bursaries on their choice of HEI: the availability of bursaries and the amount of bursary offered. To gauge the perceived effects of bursaries, all students were asked the extent to which they agreed with the statement 'Bursaries are not important in deciding where to go to university' (Table 5 Columns 1 and 2, Model 1). Note the framing of the question - we consider disagreement as a positive statement. Additionally, students were asked 'To what extent did the amount of bursary you could get influence which universities you applied to? Here we include only students who had both heard of bursaries and sought information about them because only these respondents were asked this question (Table 5 Columns 3 and 4, Model 2).

\section{INSERT TABLE 5 ABOUT HERE}

Only a minority of students perceive bursaries as important in their HE decision-making with 28 per cent disagreeing with the statement 'Bursaries are not important in deciding where to go to university' and 72 per cent agreeing. Fewer students -24 per cent - think the amount of a bursary they can get influences which universities they apply to 'somewhat' or 'a lot', whilst 76 per cent of students believe bursaries have no influence. 
The findings from the multivariate analysis give deeper insights into the role of bursary information and students' information seeking behaviour, discussed above. Predictably, those who do not think they qualify for a bursary are less likely to believe their HE choices are affected (Table 5). Moreover, students who look for information, but do not find out which university would give the largest bursary and who report that the amount of bursary does not influence to which university they apply, all agree that bursaries are not important in deciding where to go to university (Table 5 Column 1). Of those who have both heard of bursaries and looked for information, the later in the application cycle they seek bursary information, the greater the likelihood of them thinking their HE decision-making is unaffected.

Over and above the finding that only a small proportion of students think bursaries and the amount available affect their choices, another important finding is the strong correlation between the amount of bursary expected and likelihood of thinking bursaries are important. Students who believe the amount influential are 37 per cent more likely to endorse the importance of bursaries than those who do not believe this. Further, students anticipating a bursary of $£ 1,000$ or more are 11 per cent more likely to think their HEI choice is affected than students who do not apply for a bursary. There is also a strong relationship between cost-consciousness and likeliness to think bursaries important. Students who report that the costs of going to university influenced their decision to enter HE 'a lot' are up to 35 per cent more likely to believe bursaries affect their HE choice than students unconcerned about these costs. Finally, even after controlling for variations in the amount of bursary offered by different HEI types, for a given level of bursary, students of Russell Group universities are five per cent more likely than those at post-1992 institutions to agree that bursaries shaped their decision about which institution to attend.

\section{Discussion and conclusions}

A market in bursaries, unlike fees, did develop following the 2004 HE Act, with considerable variation in the nature, scope, and generosity of the bursaries offered by different HEIs. And it appears that this will continue following the 2012/13 funding reforms given the limited variability in tuition fees (OFFA, 2012b), and the diversity of institutional financial support (Diamond et al., 2012). The prevalence of discounting under the NSP through fee waivers and NSP and non-NSP bursaries makes the net prices that students pay institutions quite different from HEIs' published prices. However, our findings on bursaries introduced in 2006 suggest these discounts are likely to have had limited success in generating more user choice, provider competition, and in broadening access or acting as a financial incentive. First, our study shows that a quarter of all students surveyed do not think they have heard of bursaries. Secondly, most respondents do not think they are well informed about bursaries, unlike other forms of government financial support. Thirdly, of those who think they have heard of bursaries, one in six believe they do not know what they are, while 30 per cent say they have not looked for bursary information. Perceptions of lack of awareness, knowledge and understanding is especially pronounced amongst some of the poorest students surveyed, particularly Black students, and those attending post-1992 HEIs which have the largest proportion of 'widening participation' and low-income students. Fourthly, most students report that they look for bursary information too late in the university application cycle to inform their HE choices, and claim they are notified about their bursary eligibility and its 
value too late to influence them. Fifthly, the majority of students surveyed do not think their choice of HEI is affected by bursaries $(72 \%)$ or by the amount available $(76 \%)$. However, cost-conscious students, those anticipating a bursary of $£ 1,000$ or more, and students attending Russell Group universities are more likely to think that bursaries are important in their HE decision-making and choices. Students who believe their HE choices are constrained by their financial circumstances, who were worried about whether they could afford the costs of going to university, valued bursaries more highly maybe because they tend to be more sensitive to financial incentives. However, there are no differences in the importance attached to bursaries by students' household income, suggesting that these students' perceptions of the affordability of going to university have a stronger influence on their decision-making than their actual household income. This may be because the students surveyed only includes those from households with low to medium incomes, incomes below $£ 60,000$ per annum, and excludes students from higher income households. Unsurprisingly, students consider generous bursaries significantly more influential, particularly when worth $£ 1,000$ or more.

The overall conclusion of our findings for policy is that there is heterogeneity among students in their attitudes toward bursaries and that it may be a very individual response, which presents a challenge for policy making. However, students' lack of awareness, understanding, and knowledge of bursaries are more amenable to policy interventions, as is the timing of information provided by HEIs on whether students qualify for discretionary bursaries and how much they will receive.

Our findings reassert the significance of the asymmetry in access to information on financial support, and its importance in terms of facilitating HE access, alongside the informational challenge of comparing the costs and benefits of specific institutions, which can lead to a haphazard HE choice process (Scott-Clayton, forthcoming). They reinforce the widespread consensus amongst researchers and policymakers both here and in the US that for student financial assistance to be effective, in whatever form, it needs to be simple and easy to understand, transparent, notified early, and predictable (Dynarksi and Scott-Clayton 2006; Long 2008; NCIHE, 1997). Simplicity is needed in terms of eligibility determination and application logistics; transparency is required so students can easily understand what they need to do to qualify and what they will get if they do; and students require early notification and predictability so they can know about their university costs and financial support well in advance of their HE decision-making. Those who are unsure if university is affordable may reject higher education (Scott-Clayton, forthcoming). These design features are largely present in government-funded loans and grants, as evidenced by the students we surveyed who were familiar with this support, and national data on their high take-up rates (SLC/BIS, 2011). However, their absence, alongside poor information and marketing, help explain the limited success of bursaries reported by the students surveyed - problems likely to be repeated in the new NSP.

HEFCE, in response, issued guidance on the information that HEIs should make available on their websites about the new National Scholarship Programme, introduced in 2012/13 (HEFCE, 2011). An initial evaluation of these websites concludes that the information presented is highly variable with only a half providing full details of national and institutional eligibility criteria (Diamond et al., 2012). Yet, students need information on bursaries before 
they are asked to make enrolment decisions, and they need reliable information that will help them predict well in advance what kind of bursary or financial assistance they might expect from their institution.

This transparency, early notification and predictability are critical components in the design of effective financial support policies. However, just like the bursaries examined in our study, under the NSP 'prospective students will not receive a clear indication of whether their application for NSP will be successful prior to entry' (Diamond, 2012: 32). An examination of information provided7 by 90 HEIs in England in Spring 2012 on their student financial support including the NSP, concludes that for over 70 per cent of these universities, it would be impossible for students to deduce in advance of applying to the university how much they would receive in fee waivers and bursaries because the discretionary eligibility are not transparent. 'Students would only find out how much support they can receive after enrolling at the HEI. This uncertainty could affect students' application or participation decisions, while also increasing the likelihood of 'deadweight loss' (since the students who do end up receiving NSP awards would have been likely to attend anyway)' (Chowdry et al., 2012: 5). Under NSP, therefore, students cannot respond to a price subsidy in their HE decisionmaking, nor are National Scholarships (NSs) likely to promote informed institutional choice. Moreover, given the risk of deadweight loss, it is questionable if the current NSP is an effective means of helping low-income students overcoming the barriers to HE participation.

Just because institutions must provide information does not mean students or their families can find it easily, know what to do with it, or how to interpret it. The wide variability of discretionary bursaries makes understanding the information provided hard for students, and makes it difficult for universities to explain them clearly, undermining their effectiveness. While the take-up of the pre-2012 bursaries has been resolved through the introduction of HEBSS, the system of bursaries remains highly complex and confusing. HEIs' desire to target provision at specific student groups has created hundreds of bursary schemes, each with unique eligibility criteria and value. The trade-off between targeting financial help and simplicity produces a support system lacking in transparency and predictability (Mitton, 2007). These are the inevitable consequences of HEIs' freedom to devise their own institutional support. This complexity and confusion affects HEIs' ability to communicate clear messages and the right signals to students.

These issues are likely to become even more pronounced under the new NSP because HEIs have greater flexibility to develop their own approach. Determining exactly what a National Scholarship (NS) is, and who is eligible, is more complicated than the relatively 'straightforward' cash bursaries of old, awarded for the duration of a course. HEIs can choose how to spend their match contribution: to increase the number of scholarships or the value of each award or both. Consequently, a NS can be worth anything from the statutory minimum of $£ 3,000$ upwards - a minimum suggesting some acknowledgement of our finding about the perceived effectiveness of more valuable institutional aid. A NS can consist of any combination of: a fee waiver or discount; other benefits in kind; and a cash payment. It can be

7 The study looked at each university's website their OFFA agreement and where necessary by contacting the university's admissions office directly (Chowdry et al, 2012) 
given just in a student's first year8 and/or spread across subsequent years. Each HEI decides these features, so what a NS is varies considerably from one HEI to another. Such a system is not simple or transparent, making it hard for students to predict what they might receive, or not.

The Government has set very broad-based national eligibility criteria for the NSP related to household income, but meeting them does not equate to scholarship entitlement. As demand is likely to exceed the number of NSP awards allocated to many HEIs, HEIs are imposing varying additional local eligibility criteria. So NSs, like non-mandatory bursaries in our study, will be discretionary with eligibility varying from one HEI to another. But, the new NSP is proving to be far more complex and confusing, even less transparent and predictable than the existing system of institutional aid it will sit alongside (Chowdry et al., 2012).

When students applied for government financial support, their bursary eligibility was usually automatically assessed and allocated through HEBSS, so they made just one application for support. This largely resolved low take-up often associated with discretionary income-related benefits (Cordon, 1995). Under the NSP, HEBSS determines whether a student meets the national NSP criteria, but HEIs determine whether the applicant meets their local eligibility criteria, informs the applicant accordingly, and delivers the NSP benefits to students. This is likely to be far more onerous and costly for HEIs, and is likely to reduce NSP take-up. Moreover, with the NSP, students make two applications: one for government funding and another for a NS, making the application process more complex. These are just some of the design factors affecting take-up. As Corden (1995 p 15) warns: 'While these effects [on take-up] have traditionally been interpreted at the client level in terms of misunderstanding, or inability to make the intellectual links, they may be equally well interpreted in terms of the characteristics of the benefit itself.' One such characteristic is NSP's name. Our study questioned students' understanding of the terms 'bursaries' and 'scholarships'. Most students (81\%) believed bursaries were allocated based on a student's family income, while scholarships were awarded on a student's examination results $(68 \%)$ and other achievements (59\%). The language used to describe the NSP could confuse students and deter take-up, as the NSP scholarships are not usually merit-based. The effectiveness of the NSP rests on their characteristics, design, and how they are implemented by HEIs, as well as students' reactions to choice.

The discretionary nature of both bursaries and the NSP raise other policy issues. Policy technologies such as choice and competition recast the structure and culture of public services. Although the NSP is co-funded by the state, the main decision-making about who gets a NS and its value, has been transferred from the state to HEIs reflecting the trend in welfare provision in England, and student aid in the US (Baum et al., 2010), towards more discretionary benefits and 'localised' decision-making. Moreover, HEIs' motives for providing institutional aid vary. HEIs sometimes use bursaries more to their advantage than those of needy students, particularly when deployed as a competitive tool in admissions aimed at shaping the composition of the student body (Callender, 2010). Thus, perversely,

8 Currently, the government stipulates that its portion of the NSP must be given to students in their first year of study. 
bursaries have helped universities choose students, rather than students choose universities, which is likely to continue with the NSP.

Bursaries and the new NSP are generating new forms of inequality rather than eradicating them. Their discretionary and variable nature leads to the unequal treatment of students. The allocation of the limited number of NSP awards is determined by an HEI's total number of undergraduates not its proportion of low-income students. So there are fewer awards for lowincome students in HEIs with high proportions of them. This determines the amount of support available. Because the NSP allocations ignore the socio-economic composition of an HEI, NSP money has to be spread most thinly amongst HEIs with the highest proportion of disadvantaged students, primarily less research intensive and prestigious, post-1992 HEIs. In addition, the government's NSP contribution for each low-income student is lower at these HEIs. A more sensitive NSP allocation system could easily change this inequity.

National data show that Russell Group universities offer the most generous non-mandatory bursaries with the largest awards restricted to the brightest students. Our study confirmed this too. This matters because of our finding that students consider generous bursaries significantly more influential in their decision making. This unequal pattern of provision is being repeated and exacerbated under the new post-2012 NSP regime, with higher-ranked HEIs offering the most valuable packages of support - both in terms of cash bursaries and fee waivers. Chowdry et al. (2012: 23) estimate that a student from a family with an income of $£ 25,000$ or under could expect a total package of institutional financial support of over $£ 2,900$ a year on average at a Russell Group University compared to just $£ 700$ if they attend a Million+ HEI. Indeed, 'the average cash support available to low-income students at lowerstatus universities has actually fallen following the reforms, while it has increased among high-status universities' (Chowdry et al., 2012: 5). These cash benefits are important for students because the main alternative, tuition fee waivers, which were not present under the old system, are only of value as a potential future benefit. (If students do not pay off all their student loan in full after 30 years, a reduction in tuition fee debt will make no difference to them financially.) Under the new funding regime, lower-ranked HEIs tend to charge lower tuition fees but offer smaller fee waivers compared with Russell Group universities that have higher fees but larger fee waivers. Consequently, once fee waivers are taken into consideration, there are smaller differences in net average fees between different types of HEI. Specifically, the average fees for low-income students are lower at Russell Group universities than they are at some lower-ranked HEIs (Chowdry et al., 2012).

Consequently, under the new funding arrangements there are vast differences in financial support depending upon which HEI a student attends. Students with identical financial needs have access to very different amounts and types of financial support depending on where they study. Financial need no longer dictates which students receive financial aid or how much they are awarded. And again, this is becoming more pronounced under the new regime with the growing trend towards merit based awards as against needs-based aid. ${ }^{9}$ This marks a radical departure from the ideology of 'meeting need', entitlement, and universality, which

\footnotetext{
9 This is probably related to the government policy of allowing universities to recruit as many students as like who gain high A Level (schools leaving certificate) grades.
} 
until 2006, informed all government student-funding policies in England, and heralds the end of horizontal equity.

Finally, as Ball (2008: 149) observes, policies informed by the choice and competition agenda subordinate education to 'the economic' and render 'education itself into the commodity form.' Students are 'repositioned as consumers and entreated' to compare universities based on price. The 'logic' of these policies is that students' HE decision-making and choices are influenced by financial incentives rather than academic considerations. Rather than bursaries and the NSP eliminating high prices as a factor in students' choices, net price becomes a central feature of their decision-making.

The overall conclusion of this analysis is that the success of bursaries has been at best partial, both in generating more choice and competition, and in broadening access. Bursaries have yielded unanticipated and contradictory consequences. Most significant is the trade-off between competition and equity and how bursaries are creating new inequalities. This is important, given the introduction of the NSP, and the growing significance of institutional aid here and elsewhere. The lessons learnt from bursaries, for improving their overall effectiveness and efficiency, are yet to be transferred to the NSP.

\section{References}

Ball, S. (2008) The Education Debate, Bristol: The Policy Press.

Barr, N. (2012) The Higher Education White Paper: The Good, the Bad, the Unspeakable and the Next White Paper, Social Policy and Administration 46 (5). pp. 483-508.

Bates, P. Pollard, E. Usher, T. and Oakley, J. (2009) Who is heading for HE? Young People's Perceptions of, and Decisions about, Higher Education BIS Research Paper 3, London: Department for Business, Innovation and Skills.

Baum, S., Lapovsky, L and Ma, J. (2010) Tuition Discounting: Institutional Aid Patterns at Public and Private Colleges and Universities, 2000-01 to 2-8-09 College Board http://advocacy.collegeboard.org/sites/default/files/10b_1976_TuitionDiscountReport_Int_W EB 100910.pdf Accessed 26/08/2012

Baum, S. McPherson, M. and Steele, P. (2008) (Eds.), The effectiveness of student aid policies: What the research tells us (pp. 9-38). The College Board, New York

Callender, C (2013) The Funding of Part-time Undergraduate Students In D. Heller and C. Callender (eds) Student Financing of Higher Education: A Comparative Perspective, International Studies in Higher Education London: Routledge

Callender, C (2012) 'The 2012/13 reforms of higher education in England: changing student finances and funding' in Majella Kilkey, Gaby Ramia, Kevin Farnsworth (eds) (2012) Social Policy Review 24: Analysis and debate in social policy 2012, Bristol: Policy Press pp 77-96 Callender, C. (2010) Bursaries and Institutional Aid in Higher Education in England: Do they safeguard access and promote fair access? Oxford Review of Education Vol 36:1 pp 45-62 Callender, C. (2009a) Awareness, Take-Up and Impact of Institutional Bursaries and Scholarships in England: Summary and Recommendations, Bristol: Office for Fair Access, 44 pp http://www.offa.org.uk/wp-content/uploads/2009/12/OFFA-2009.07-summary-andrecommendations.pdf 
Callender, C. (2009b) Strategies undertaken by Higher Education Institutions in England to increase awareness, knowledge, and take-up of their bursaries and scholarships, Bristol: Office for Fair Access, $55 \mathrm{pp}$ http://www.offa.org.uk/publications/

Callender, C. (2009c) Awareness and knowledge of institutional bursaries and scholarships among higher education advisors in schools and college in England, Bristol: Office for Fair Access, $52 \mathrm{pp}$ http://www.offa.org.uk/publications/

Callender, C. and Hopkin, R. (2009) Awareness and knowledge of institutional bursaries and scholarships among the parents of higher education students in England, Bristol: Office for Fair Access, 42pp. http://www.offa.org.uk/publications/

Callender, C. Wilkinson, D. and Hopkin, R. (2009) The impact of institutional financial support in England: higher education students' awareness, knowledge and take-up of bursaries and scholarships, Bristol: Office for Fair Access, 199 pp http://www.offa.org.uk/publications/

Chowdry, H., Dearden, L., Jin, W. and Lloyd, B (2012) Fees and student support under the new higher education funding regime: what are different universities doing? Institute for Fiscal Studies, IFS Briefing Note, London http://www.ifs.org.uk/publications/6429 Accessed 03/05/2017

Clarke, J. Newman, J. Smith, N. Vindler, E. and Westerland, L. (2007) Creating CitizenConsumers: Changing Publics and Changing Public Services, London: Paul Chapman Publishing

College Board (2011) Trends in College Pricing 2011, New York: The College Board.

Corver, M. (2010) Have bursaries influenced choices between universities? Bristol: Office for Fair Access

Corden, A. (1995) Changing Perspectives on Benefit Take-up London: HMSO

Davies, P. Slack, K. Hughes, A. Mangan, J. and Vigurs, K. (2008) Knowing Where to Study? Fees, Bursaries and Fair Access, Institute for Educational Policy Research and Institute for Access Studies, Stoke on Trent: Staffordshire University

Department for Business, Innovation and Skills (2011) Higher Education: Students at the Heart of the System $\mathrm{Cm}$ 8122, London: Stationery Office

Diamond, A., Bowes, L., Michael, A., Thomas, L., Porter, A., and Sheen, J. (2012) Formative Evaluation of the National Scholarship Programme Bristol: Higher Education Funding Council http://www.hefce.ac.uk/pubs/rereports/year/2012/nspevaluation/ Accessed $24 / 08 / 2012$

Dynarski, S. M., and Scott-Clayton, J. (2006) "The cost of complexity in federal student aid: Lessons from optimal tax theory and behavioral economics," National Tax Journal, 59(2): 319-356.

Hills J. and Richards, B (2012) Localisation and the means test: A case study of support for English students from Autumn 2012 Centre for Analysis of Social Exclusion Discussion Paper 160, London: London School of Economics

HEFCE (2011) National Scholarship Programme 2012-13 Guidance for institutions Bristol; HEFCE http://www.hefce.ac.uk/pubs/hefce/2011/11_10/11_10.pdf Accessed 26/08/2011

Hossler, D., Schmit, J. and Vesper, N. (1998). Going to college: Social, economic and educational factors' influence on decisions students make. Baltimore: Johns Hopkins University Press. 
Johnson, C. Pollard, E. Hunt, W. Munro, M. and Hillage, J. (2009) Student Income and Expenditure Survey 2007-08 English Domiciled Students, DIUS Research Report 09 05, London: Department for Innovation, Universities and Skills.

Johnstone, D.B. and Marcucci, P. (2010) Financing Higher Education Worldwide: Who Pays? Who Should Pay? Baltimore: John Hopkins University Press

Kerr, S. (1982) Deciding about Supplementary Pensions: a provisional model, Journal of Social Policy 11:4 pp 505-17

Kettley, N. Whitehead, J. and Raffan, J. (2007) Worried women, complacent men? Gendered responses to differential student funding in higher education, Oxford Review of Education Vol 34:1 pp 111-129

London Economics (2010) Review of Student Support Arrangements in Other Countries BIS Research Paper No 10, London: Departments for Business, Innovation and Skills http://www.bis.gov.uk/assets/biscore/corporate/docs/r/10-670-review-student-support-in-

other-countries.pdf;

Long, B. (2008) "What Is Known About the Impact of Financial Aid? Implications for Policy." New York: National Center for Postsecondary Research (NCPR) Working Paper. Accessed $20 / 08 / 2010$

http://www.postsecondaryresearch.org/i/a/document/6963_LongFinAid.pdf

Mitton, L. (2007) Means-tested HE? The English university bursary mess Journal of Further and Higher Education Vol 31:4 p373-383

Mundel, D. S. (2008). What do we know about the impact of grants to college students? In S. Baum, M. McPherson and P. Steele (Eds.), The effectiveness of student aid policies: What the research tells us (pp. 9-38). The College Board, New York

National Audit Office (2008) Widening Participation in Higher Education HC 725 Session 2007-2008,

National Committee of Inquiry into Higher Education [The Dearing Report] (1997) Higher Education in the Learning Society London: HMSO

OFFA (2012a) Access agreement and widening participation strategic assessment monitoring: Outcomes for 2010-11 http://www.offa.org.uk/wpcontent/uploads/2012/07/2012-05+2012-13-OFFA+HEFCE-Access-Agreement-outcomes-

web.pdf Access 23/08/2012

OFFA (2012b) 2013-14 access agreements: institutional expenditure and fee levels http://www.offa.org.uk/wp-content/uploads/2012/07/2013-14-access-agreements-

institutional-expenditure-and-fee-levels.pdf Access 23/08/2012

OFFA (2010) The Independent Review of Higher Education Funding and Student Finance First call for evidence Submission by the OFFA, Bristol: OFFA. Accessed 30/06/2010 http://www.offa.org.uk/publications

Reay, D. (2012) Universities and the reproduction on inequality in J. Holmwood (ed.) A Manifesto for the Public University, London: Bloomsbury Academic

Reay, D. David, M. and Ball, S.J. (2005) Degrees of Choice: social class, race and gender in higher education, Stoke on Trent:Trentham Books.

Scott-Layton, K (forthcoming) Information Constraints and Financial Aid Policy. In D. Heller and C. Callender (eds) Student Financing of Higher Education: A Comparative Perspective, International Studies in Higher Education London: Routledge 
Student Loan Company/ Department for Business, Innovation and Skills (2011) Student Support for Higher Education in England, Academic Year 2011/12 (Provisional) SLC SFR 06/2011 http://www.slc.co.uk/media/140371/slcsfr062011.pdf Accessed 03/05/2017

Usher, T. Baldwin, S. Munro, M. Pollard, E. and Sumption, F. (2010) The role of finance in the decision-making of $H E$ applicants and students BIS Research Paper No 9, http://www.employment-studies.co.uk/pdflibrary/bis10529.pdf Accessed 30/02/2010

Vindler, E. and Clarke, J. (2005) Creating Citizen Consumers: New Labour and the remaking of public services Public Policy and Administration No 20 Vol 2 19-37. 


\section{Ethnicity}

\section{Gender}

Age

$\% \quad \mathbf{N}$

$\begin{array}{rrr}\text { Female } & 57 & 2746 \\ \text { Male } & 43 & 2102\end{array}$

24 years or under $87 \quad 4227$

25 years or over

$13 \quad 621$

\begin{tabular}{rrr} 
White & 73 & 3557 \\
Mixed & 3 & 164 \\
Asian & 11 & 515 \\
Black & 7 & 347 \\
Other & 2 & 87 \\
Refused & 4 & 178 \\
Household income & & \\
Low-income group $(<£ 5,000)$ & 30 & 1461 \\
Middle income group $(>£ 5,000-$ & 36 & 1754 \\
High income group (>£25,000) & 33 & 1633 \\
Parents no HE qualifications & & \\
Parents hold HE qualifications & 50 & 2421 \\
Don't know/NA/not answered & 35 & 1716 \\
Single, no children & 15 & 711 \\
Family type $\quad$ & 91 & 4435 \\
Single, dependent children & 3 & 169 \\
Married/cohabiting, no children & 3 & 125 \\
Married/cohabiting, dependent children & 2 & 119 \\
\hline
\end{tabular}

$\begin{array}{lll}\text { All Students } & 100 & 4848\end{array}$

Base: All students who had heard of bursaries

Source: Birkbeck Survey of Students, 2008 
ALL

ALL

$\% \quad \mathbf{N}$

Where existing qualification

Was undertaken

$\begin{array}{rrr}\text { FE college } & 65 & 3146 \\ \text { State school } & 26 & 1270 \\ \text { Not answered } & 7 & 363 \\ \text { endent school } & 2 & 80\end{array}$

HEI type/mission group

$\begin{array}{rrr}\text { Russell group } & 19 & 919 \\ 1994 \text { group } & 12 & 595 \\ \text { Pre-199210 } & 9 & 459 \\ \text { Post-1992 } & 59 & 2874\end{array}$

HEI HEBSS status

$\begin{array}{rrr}\text { Full } & 78 & 3787 \\ \text { Information only } & 18 & 869 \\ \text { None } & 4 & 191\end{array}$

Studying strategically important or

vulnerable subject (siv)?

Not studying SIV $\quad 84 \quad 4067$

$\begin{array}{lll}\text { Studying SIV } & 16 & 781\end{array}$

$\begin{array}{lll}\text { N Weighted } & 100 & 4848\end{array}$

Base: All students who had heard of bursaries

Source: Birkbeck Survey of Students, 2008

10 Pre 1992 universities do not include those who are members of the Russell Group or the 1994 Group 
Table 3 The associations between key socio-economic characteristics and students' likelihood to have not heard of bursaries from universities

\section{Student had not heard of}

bursaries from universities

Gender (base: female)

Marginal effect Standard error

Age (base: 24 vears or under)

Male

0.01

$(0.01)$

Ethnicitv (base: White)

25 years or over

0.03

$(0.03)$

Mixed

Asian

0.03

$(0.04)$

Black

$0.08 *$

$(0.02)$

Other

$0.07 *$

$(0.03)$

$-0.01$

$(0.05)$

Household income (base: $\leq \mathbf{\$ 5 , 0 0 0 )}$

Refused

0.01

(0.04)

$>£ 5.000 \& \leq £ 25.000$

0.02

$(0.02)$

$0.15^{*}$

$(0.02)$

\section{Parent HE qualifications}

(base: parents no HE qualifications)

Dependency (base: dependent)

Parents hold HE qualifications

Don't know/NA/not answered

0.01

$(0.01)$

0.03

Family type (base: single, no children)

$$
\text { Independent }
$$

0.02

Single, dependent children

Married/cohabiting, no children

Married/cohabiting, dependent children

$-0.05$

$-0.04$

$-0.03$

\section{Living arrangements}

With my parents/family

In other rented accommodation

$-0.00$

$0.07 *$

0.03

$(0.04)$

Not answered

Where existing qualification was

$-0.12$

undertaken

(base: FE college)

$$
\begin{array}{r}
\text { State school } \\
\text { Private/independent school } \\
\text { Not answered }
\end{array}
$$

$-0.03$

$-0.00$

$-0.05$

HEI type (base: post-1992)

$-0.10 *$

$(0.02)$

$-0.06^{*}$

$(0.02)$

1994

Pre-1992

$-0.01$

HEI HEBSS status (base: full)

$\begin{array}{ll}-0.07 * & (0.02) \\ -0.03 & (0.03)\end{array}$

Studying strategically important or

$$
\text { None }
$$


studying SIV)

Studying SIV $\quad-0.00 \quad(0.02)$

\begin{tabular}{lc}
\hline Number of observations & 4825 \\
Pseudo R-squared & 0.0402
\end{tabular}

Base: All students

Notes: Marginal effect reports the discrete change in predicted probability associated with the presence of the stated characteristic, as opposed the base condition

* indicates differences significant at 5 per cent level

Source: Birkbeck Survey of Students, 2008 
Table 4 The associations between key socio-economic characteristics and information search behaviour and whether students understood what is meant by a bursary

Understands what is meant by a bursary

$\begin{array}{cc}\text { Marginal } & \text { Standard error } \\ \text { effect } & \end{array}$

Gender (base: female)

Age (base: 24 years or under)

$$
\text { Male } \quad 0.03^{*}
$$

\section{Ethnicity (base: White)}

$$
25 \text { years or over } \quad-0.03
$$

$$
\begin{aligned}
\text { Mixed } & 0.05^{*} \\
\text { Asian } & -0.01 \\
\text { Black } & -0.06^{*} \\
\text { Other } & -0.01 \\
\text { Refused } & -0.07
\end{aligned}
$$

Household income (base: $\leq £ 5,000)$

$$
\begin{array}{rll}
>£ 5,000 \& & \leq £ 25,000 & 0.04^{*} \\
> & >25,000 & -0.01
\end{array}
$$

Parent HE qualifications (base: parents no HE

$$
\begin{array}{ccc}
\text { Parents hold HE qualifications } & -0.01 & (0.01) \\
\text { Don't know/NA/not answered } & -0.00 & (0.02)
\end{array}
$$

Dependency (base: dependent)

Family type (base: single, no children)

$$
\text { Independent } \quad 0.02 \quad(0.02)
$$

$$
\text { Single, dependent children } \quad 0.05^{*} \quad(0.03)
$$

$$
\begin{array}{rll}
\text { Married/cohabiting, no children } & 0.00 & (0.04) \\
\text { Married/cohabiting, dependent children } & 0.04
\end{array}
$$

Living arrangements (base: university provided

$\begin{array}{ll}-0.00 & (0.02) \\ -0.02 & (0.02) \\ -0.04 & (0.04) \\ -0.06 & (0.11)\end{array}$

Where existing qualification was undertaken (base:

$$
\begin{array}{r}
\text { With parents/family } \\
\text { Other rented accommodation } \\
\text { Other } \\
\text { Not answered }
\end{array}
$$

\section{State school}

HEI type (base: post-1992)

Not answered

$$
0.11^{*}
$$

HEI HEBSS status (base: full)

$$
\begin{array}{rc}
\text { Russell } & 0.08^{*} \\
1994 & 0.04^{*} \\
\text { Pre-1992 } & 0.03
\end{array}
$$

$1994 \quad 0.04 * \quad(0.02)$

Studying strategically important or vulnerable

$$
\begin{array}{rll}
\text { Information only } & 0.03 * & (0.02) \\
\text { None } & -0.03 & (0.03)
\end{array}
$$

$$
\begin{array}{lll}
\text { Studying SIV } & 0.00 \quad(0.02)
\end{array}
$$

There is not enough information about bursaries

$$
\text { Agree } \quad-0.10 * \quad(0.01)
$$




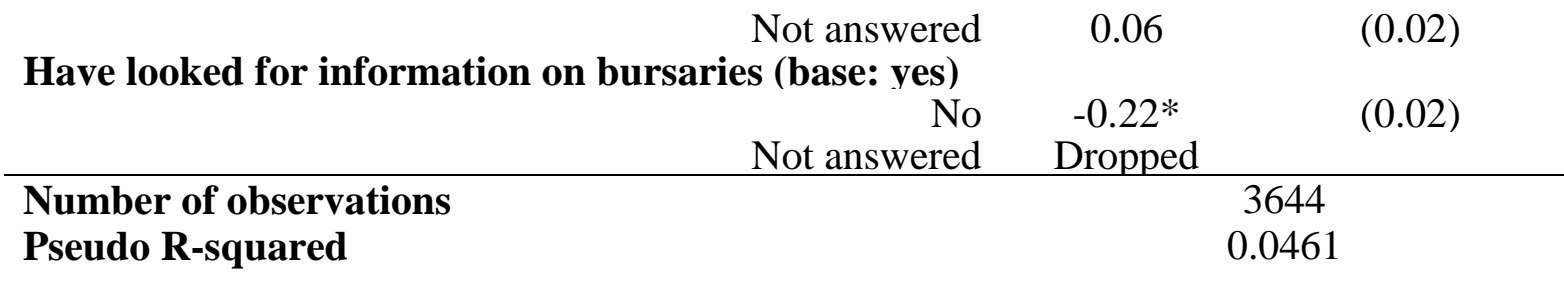

Base: Students who had heard of bursaries

* indicates differences significant at 5 per cent level,

Source: Birkbeck Survey of Students, 2008 
Table 5 Marginal effect estimates of student perceptions of the impact of bursaries on university choice

Disagree or partially
disagree that bursaries
are not important in
deciding where to go to
university

Gender (base: female)

Age (base: 24 years or under)

Ethnicity (base: White)

25 years or over

Mixed

Asian

Black

Other

Household income (base: $\leq \mathfrak{\$ 5 , 0 0 0 )}$

Refused

$$
\begin{aligned}
>£ 5,000 \& & \leq £ 25,000 \\
& >£ 25,000
\end{aligned}
$$

Parent HE qualifications

(base: parents no HE qualifications)

$$
\text { Parents hold HE qualifications }
$$

Don't know/NA/not answered

Dependency (base: dependent)

Independent

Family type (base: single, no children)

Single, dependent children Married/cohabiting, no children Married/cohabiting, dependent children

Living arrangements

(base: university provided

$$
\text { With parents/family }
$$

Other rented accommodation

Other

Where existing qualification was

Not answered undertaken (base: FE college)

State school

Private/independent school

HEI tvpe (base: post-1992)

Not answered

Russell
1994

\section{Marginal \\ effect}

$-0.01$

0.04

$0.09 *$

$-0.01$

$-0.03$

0.00

$0.09 *$

0.00

0.02

$-0.03$

$-0.01$

(0.02)

(0.02)

$-0.02$

(0.03)

(0.04)

(0.02)

(0.03)

(0.05)

(0.04)

(0.02)

(0.02)

$-0.01$

$-0.05$

$-0.03$

(0.04)

(0.04)

$-0.01$

$-0.01$

$-0.04$

$-0.10$

(0.02)

$(0.02)$

(0.04)

(0.09)

0.02

0.01

0.03

$0.05^{*}$

$-0.02$
(0.02)

$(0.03)$

(0.06)

(0.02)

(0.02)
(0.05)
The amount of

bursary a student

could get influenced

which university

Model 2 
HEI HEBSS status (base: full)

Information only

None

Studying strategically important or vulnerable subject (SIV)? (base: not studying SIV)

Extent costs influence your decision to

$$
\text { Studying SIV }
$$
attend university? (base: not at all)

A lot

Somewhat

Not answered

Whether think qualify for a

bursary?(base: yes)

No
Not answered

Whether heard of bursaries? (base: yes)

Whether looked for information on

No

$-0.02$

bursaries? (base: no)

$$
\begin{aligned}
& \text { Yes } \\
& \text { Parents found out for me } \\
& \text { which university }
\end{aligned}
$$

\section{which university}$$
-0.10^{*}
$$

$0.35^{*}$

$0.16^{*}$

$0.32 *$

$0.11 *$

$-0.04 *$

$-0.12$

$(0.02)$

$(0.09)$

$-0.11^{*}$

0.08

$(0.03)$

$(0.02)$

$(0.04)$

would give the largest bursary? (base: no)

Extent to which the amount of bursary

$$
\text { Yes }
$$

$0.09 *$

influenced which universities applied to (base: not at all)

A lot

$0.37 *$

$0.23 *$

Somewhat

When looked for information on bursaries? (base: before applying to university)

When doing my UCAS application After submitting my UCAS application After I was offered a place at university When applying for student financial support After my university confirmed my place

0.00

$-0.01$

$-0.01$

$-0.03$

$-0.02$

$(0.03)$

$-0.11 *$

0.01

$(0.03)$

$-0.10 *$

$-0.03$

$(0.03)$

$-0.14 *$

When I received a letter from my university

$-0.04$

$(0.05)$

$-0.12 *$ Not answered

Which source of bursary information was

$(0.05)$

$-0.12^{*}$ 
the most helpful? (base: HEI source)

$\begin{array}{rrrrr}\text { School or college source } & 0.05 & (0.03) & 0.03 & (0.03) \\ \text { Personal networks } & 0.01 & (0.03) & -0.01 & (0.03) \\ \text { Other sources } & -0.04 & (0.03) & -0.04 & (0.02) \\ \text { Not answered } & 0.01 & (0.07) & 0.00 & (0.04)\end{array}$

How much bursary do you hope to receive in your first year of study?

(base: have not applied for a bursary)

$\begin{array}{rrr}\leq £ 310 & -0.03 & (0.04) \\ >£ 310 \& \leq £ 500 & 0.00 & (0.04) \\ >£ 500 \& \leq £ 1000 & 0.02 & (0.03) \\ >£ 1,000 & 0.11^{*} & (0.04) \\ \text { not receive a bursary } & 0.02 & (0.06) \\ \text { Not answered } & 0.00 & (0.03)\end{array}$

Have been told I will not receive a bursary

Not answered

\begin{tabular}{lcc}
\hline Number of observations & 4777 & 2537 \\
Pseudo R-squared & 0.0599 & 0.1095 \\
\hline
\end{tabular}

Base: All students who answered question whether bursaries were important in deciding where to go to university.

Notes: Marginal effect reports the discrete change in predicted probability associated with the presence of the stated characteristic, as opposed the base condition

* indicates differences significant at 5 per cent level

Source: Birkbeck Survey of Students, 2008 